\title{
Relationships among Service Quality, Customer Satisfaction and Customer Perceived Value: Evidence from Iran's Software Industry
}

\author{
Seyed Mostafa Razavi
}

\author{
Management Department \\ University of Tehran \\ Tehran, Iran
}

Tel: +98-912-130-7051Ｅ-mail: mrazavi@ut.ac.ir

\author{
Hossein Safari \\ Management Department \\ University of Tehran \\ Tehran, Iran
}

Tel: +98-912-136-1150Ｅ-mail: hsafari@ut.ac.ir

\author{
Hessam Shafie (Corresponding author) \\ Industrial Management \\ University of Tehran \\ Tehran, Iran
}

Tel: +98-912-608-6787 E-mail: hshafie@alumni.ut.ac.ir

Kobra khoram

Master of Business Administration

Payamenoor University

Tehran, Iran

Tel: +98-912-545-2735_E-mail:khoram_kobra@yahoo.com

Received: June 3, 2012

doi: $10.5430 /$ jms.v3n3p28
Accepted: June 25, 2012

Published: June 30, 2012

URL: http://dx.doi.org/10.5430/jms.v3n3p28

\begin{abstract}
This study sets out to investigate the relationships service quality, customer perceived value and customer satisfaction in six large software companies of Iran. To this end, after reviewing the related literature, the effective factors in the service quality, customer perceived value and customer satisfaction were identified. Then, questionnaires were distributed among the customers of the companies. Next, Factor Analysis and Structural Equation Modelling were used to find the relationships; as a result, the proposed model was extracted. According to findings, there are significant and positive relationships between service quality and customer perceived value, service quality and customer satisfaction and customer perceived value and customer satisfaction in these companies. Furthermore, service quality can predict customer satisfaction more than what customer perceived value does.
\end{abstract}

Keywords: Service Quality, Customer Satisfaction, Customer Perceived Value, Structural Equation Modelling (SEM), Software Companies

\section{Introduction}

It is often pointed out that customer satisfaction should be the ultimate goal of all firms (Morgan et al, 2005). In the 
same line, empirical evidence supports this view, arguing that customer satisfaction reduces the defection and/or is positively associated with retention; repurchase intention, and loyalty (Cameranet al., 2010). Since services have intangible natures, Cameran et al (2010) add that the association between customer satisfaction and the attributes of service has proved difficult to pin point. According to Hellier et al (2003) there is not a consensus as for the relationship between quality and satisfaction at both the transaction-specific and global level of analysis. Although a plethora of research has been done on customer satisfaction in the context of consumer services, business-to-business services have rarely been addressed (Paulssen and Birk, 2007). Also, recognition of customer perceived value has been pointed out as one of the most important measures in gaining a competitive edge (Parasuraman, 1997) and a key factor in strategic management (Burns and Woodruff, 1992).

It is known that service quality (Chang and Wang,2011; Saha and Theingi,2009) and customer perceived value(lai et al, 2009; Edward \& Sahadev,2011) have significant effects on customer satisfaction. Taking these lines of research into account, this study sets out to investigate the relationships among service quality, customer perceived value and customer satisfaction in six large software companies of Iran. To this end, after reviewing the literature and identifying the indicators, a questionnaire was distributed among customers and 354 questionnaires were completed. Eventually, Structural Equation Modeling (SEM) was utilized. Findings attempted to shed some light on the relationship among service quality, customer perceived value and customer satisfaction in software industry of Iran.

\section{Literature Review}

\subsection{Service Quality ( $S Q$ )}

Service quality is an important issue in service management (Clottey et al, 2008); besides, with the development of the service sector, the notion of service quality has become increasingly significant (Ma et al, 2005). In the related literature, Plausible definitions for service quality have been suggested, Parasuraman et al (1988), define Customer perceived service quality as a global judgment or attitude related to the superiority of a service relative to competing offerings. According to Bitner and Hubbert (1994), it is the customer's overall impression of the relative inferiority/superiority of the organization and its services. Zeithaml and Bitner (1996) see service quality as the delivery of excellent or superior service relative to customer expectations. Gronroos (1984), depicts the concept as "the outcome of an evaluation process, where the consumer compares his expectations with the service he perceives he has received" (p. 37).

Among others, two main theoretical constructs seem outstanding. The European school of thought led by the work of Gronroos (1984), undoubtedly serves as the pivot on which studies on the conceptualisation of service quality turn. This school of thought put forward that customers perceive service quality from two viewpoints: the technical quality and the functional quality of the service. Technical quality has to do with the question if the service meets customers' expectations. The functional quality measures how customers perceive the production and delivery of the service. While this dichotomy is technically viable, both are required to influence customers' service quality evaluations and loyalty behaviours (Richard and Allaway, 1993). The European school has been criticized on the grounds that it excludes the service physical environment. The other conceptualisation of service quality- the American school of thought hinges upon the work of Parasuraman et al., (1985, 1988 and 1994) and Parasuraman et al. (1991). This view has been adopted by a number of scholars researching service quality.

Parasuraman et al., (1985 \& 1988) conceptualised service quality as the overall assessment of the difference between perception and expectation of service delivery.In this model, which has been regarded as the most prominent, through a series of focus group sessions, 10 dimensions of service quality that are generic and relevant to services in general were uncovered. These dimensions are tangibles, reliability, responsiveness, communication, credibility, security, competence, courtesy, understanding the customer and access. In later studies, the dimensions have been condensed into five ones by using factor analysis: tangibles, reliability, responsibility, assurance and empathy. (Parasuraman et al., 1988)

The following are the definitions of the final dimensions:

Tangibles: Physical facilities, equipment, and appearance of personnel.

Reliability: Ability to perform the promised service dependably and accurately.

Responsiveness: Willingness to help customers and provide prompt service.

Assurance: Knowledge and courtesy of employees and their ability to inspire trust and confidence.

Empathy: Caring, individualized attention the firm provides its customers. (Zeithaml et al., 1990 ).

To confirm the validity of SERVQUAL model in the evaluation of service quality, Zeithaml et al (2006), states that "service quality is a focused evaluation that reflects the customers perception of reliability, assurance, responsiveness, empathy, and tangibles” (p. 106-107). 


\subsection{Customer Perceived Value (CPV)}

Customer Perceived value is a notion that has lately been receiving attention from industrial marketing researchers (Boksberger \& Melsen,2011; Eggert and Ulaga,2006; Fiol and Alcaniz,2009; Sanchez et al,2006; Teas \& Agarwal, 2000). As a rule of thumb, offering high value to customer is a key factor for creating and maintaining long-term customer-supplier relationships. (Fiol and Alcaniz,2009). Moreover, business organizations need to become suppliers of value while each must do it in a different way from the others; taking this into account, this skill will allow them to distinguish themselves, improve their results and increase their future survival prospects (Roig et al,2009)

Overall, customer perceived value is a comparison of weighted "get" attributes to "give" attributes (Heskett et al.,1994). Roig et al,(2009)define it as a construct formed by two parts, one of benefits received (economic, social and relational) and the other of sacrifices made (price, time, effort, risk and convenience) by the customer. It's worth noting that the general definition of value is a consumer's perception of the subjective worth of some activity or object considering all net benefits and costs of consumption (Babin et al., 1994).

\subsection{Customer Satisfaction (CSAT)}

Satisfaction is defined as "the consumer's fulfillment response", a post consumption judgment by the customer that a service provides a pleasing level of consumption-related fulfillment, including under- or over-fulfillment Oliver (1997, p. 13). Boshoff and Gray (2004) point out that satisfaction is not inherent in the product or the service itself; rather, satisfaction primarily depends on the customer's perceptions of the attributes of the product or service as they relate to that individual. Therefore, different customers will express varying levels of satisfaction for the same experience or service encounter (Ueltschy et al, 2007).

\subsection{Hypotheses and Proposed Model}

Customer perceived value is also what customers want from the product or service. In many cases, quality of the product or service and the benefits it offers often become customer perceived value drivers (Bolton and Drew, 1991; Zeithaml, 1988). Many studies support this association. ( e .g . Andreassen and Lindestad, 1998 ; Chang and Wang,2011; Edward \& Sahadev,2011; Erdem and Swait,1998; Hellier et al.,2003; lai et al, 2009)

$\mathrm{H}_{1}$ : Service quality has a significant positive effect on customer perceived value

Yi (1990) believes that service quality is a vital determinant of customer satisfaction. The rationale behind this belief is that high-quality services offered by a firm would lead to customer satisfaction. This is perceived as a common phenomenon in service industry. The nature of this service quality and satisfaction link is viewed as linear, demonstrating that higher levels of service quality result in higher levels of satisfaction (Pollack, 2008). Shin and Kim (2008) maintain that service quality is a customer's overall impression of the relative efficiency of the service provider. They add that service quality is significantly related to customer satisfaction. Also, several empirical studies confirm that a higher level of service quality is related to a higher level of customer satisfaction (Andreassen and Lindestad, 1998; Chang and Wang,2011; Cronin et al, 2000; Deng et al,2010; Fornellet al., 1996; Edward \& Sahadev,2011; Oliver, 1999; Saha and Theingi,2009; Spreng and Mackoy, 1996 ; Yang et al., 2009;Wang,2010).

$\mathrm{H}_{2}$ : Service quality has a significant, positive effect on customer satisfaction.

Fornell et al., (1996) state that the main two determinants of customer satisfaction are perceived quality and perceived value. Woodruff (1997) reports that the perceived value reflects the customers' cognitive perception of the relational exchange with their providers and satisfaction mirrors the general feeling derived from the value perceived by the consumer. Roig et al, 2009 state that perceived value has an indirect effect on loyalty via satisfaction. There also exists empirical evidence demonstrating the positive relationship between perceived value and satisfaction (Anderson \& Mittal, 2000; Chang and Wang,2011; Cronin et al., 2000; Edward \& Sahadev,2011; Hellier et al.,2003; Hume \& Mort, 2010; Lai et al,2009; Lam et al., 2004; Roig et al,2009; Yang \& Peterson, 2004)

$\mathrm{H}_{3}$ : customer perceived value has a significant, positive effect on customer satisfaction.

The conceptual model incorporating the research hypotheses is shown in the figure 1.

\section{Research Methodology}

\subsection{Research Method and Sample Size}

This study used second source (library and other recorded observations) data and case study. First, the literature of service quality, customer perceived value, customer satisfaction and SEM was reviewed. After extracting criteria, 354 completed questionnaires from the customers of six large software companies in Iran were gathered. Finally, using structural equation modeling (SEM) by Lisrel 8.5 software, analysis of output was conducted. The rationale behind 
utilizing structural equation modeling is that it investigates the multivariate dependence relationships simultaneously (Molinari et al, 2008).

The formal survey was conducted based on the preliminary survey. This took approximately six months, from July to December 2011.

\subsection{Measurement}

Three questionnaires were adapted; one from Kettinger and Lee (1997) and Kettinger et al, (2009) for measuring service quality, one from Eggert and Ulaga (2002) for measuring customer perceived value and one from Lam et al. (2004) for measuring customer satisfaction. In this research factor analysis was used for considering the structure of research. Exploring factor analysis was utilized to investigate the construction of the questionnaire. Factor analysis depicted that all the mentioned dimensions are measured in all parts of the questionnaire.

\subsection{Reliability and Validity}

\subsubsection{Reliability}

The summary statistics of formal survey are shown in Table 1. For reliability evaluation Cronbach's alpha was utilized. The Cronbach's alpha reliability of all the latent variables are more than $0.6(\alpha>0.6)$, that indicates all scales demonstrate good reliability.

\subsubsection{Validity}

For evaluating validity of questionnaires, we used content validity and construct validity.

a. Content Validity

Content validity assured us that all aspects and parameters that have an impact on main content were evaluated. For testing content validity after devising a framework for the questionnaire, we asked 18 experts to modify it if needed. These experts evaluated all implemented criteria in the questionnaire and modified it.

\section{b. Construct Validity}

In this research we used factor analysis to investigate the structure of research. Exploring factor analysis and criteria factor were used to investigate the construction of the questionnaire. Factor analysis depicted that all the mentioned criteria are measured in both parts of the questionnaire.

\section{Data Analysis}

Data analysis accomplished by inferential statistics techniques particularly exploratory and confirmatory factor analysis. In this stage, 17 variables related to service quality, 3 variables related to customer perceived value and 4 variables related to customer satisfaction are factored through factor analysis method. Results are shown in Table 1.

The relationships among variables are identified using exploratory factor analysis and then the factoring is implemented. The result is fed into structural equation modeling (SEM) used in confirmatory factor analysis. The variables are properly factored during the exploratory factor analysis. Through confirmatory factor analysis in structural equation modeling (SEM) factoring is either accepted or rejected.

The software SPSS 18.0 is used for the first analysis and Lisrel 8.53 is used for the second. In the following sections the results of exploratory factor analysis and after that the results of SEM are presented.

\subsection{The Results of Confirmatory Factor Analysis}

\subsubsection{Measurement Model of Service Quality}

In the initial step confirmatory factor analysis was applied in Lisrel 8.5 and eventually path diagram of model was conducted as in Figure 2. We have tested relationship between SQ latent and its indicators. Fitness's indices in 2 show good fitness of our model, proving that selected indicators are good representatives for each dimension of service quality. Also sevice quality is defined as a higher-order construct which represents (a) Tangible, (b) Reliability, (c) Responsiveness, (d) Assurance, (e) Empathy.

Figure 2 shows the extent to which each variable describes SQ. The ranking of the variables is as follows:

1. Empathy, 2. Assurance, 3. Reliability, 4. Tangible, 5.Responsiveness.

\subsubsection{Structural Model; Relationship among Service Quality, Customer Perceived Value, Customer Satisfaction}

For entering data gathered from questionnaires in SEM for investigating our main hypothesis, we define a new variable for every latent variable and use the mean of scored answers. So we define 7 variables. In other words, we performed 
our structural model applying 5 dimensions of service quality, 1 component of customer perceived value and 1 component of customer satisfaction.

As shown in Figure 3, service quality can determine 58 percent of customer perceived value variances playing a significant role; service quality can determine 67 percent of customer satisfaction variances playing a significant role; finally, customer perceived value can determine 15 percent of customer satisfaction variances playing a significant role. Therefore, the hypotheses were confirmed.

Fitness's indices in Table 3 show a good fitness of the structural model.

\section{Conclusion}

This study intended to investigate the relationship among service quality, customer perceived value and customer satisfaction in software industry of Iran. To do so, first we studied the related literature and extracted impressive criteria on customer loyalty, corporate image, and customer satisfaction. Then we developed a questionnaire and distributed it among the customers. Eventually, we analyzed the output from questionnaires using SEM.

Caution must be exercised when treating the findings of this study due to some limitations. First, we measured all constructs in our conceptual model with one survey conducted at the same time. Second, there might be other variables and moderators (e.g., customer perceived value) that might have mediating role the variables that we considered.

In spite of the aforementioned limitations, there seem to be important managerial implications obtained from the findings. We found that customer satisfaction and corporate image are antecedent of customer loyalty in Iran's software industry; besides, customer satisfaction is strongly related to corporate image in this industry. An important point is that the relationship between service quality and customer satisfaction has been stronger than that of customer perceived value and customer satisfaction. Given that, software managers should pay more attention to improving service quality than its cost in order to improve customer satisfaction.

The obtained results in this research are in line with other research findings. They confirmed the relationship between service quality and customer perceived value highlighted in the previous research (Andreassen and Lindestad, 1998 ; Chang and Wang,2011; Erdem and Swait,1998; Hellier et al.,2003; lai et al, 2009; Edward \& Sahadev,2011), Relationship between service quality and customer satisfaction.( Anderson \& Mittal, 2000; Chang and Wang,2011; Cronin et al., 2000; Edward \& Sahadev,2011; Hellier et al.,2003; Hume \& Mort, 2010; Lai et al,2009; Lam et al., 2004; Roig et al,2009; Yang \& Peterson, 2004) and relationship between customer perceived value and customer satisfaction (Anderson \& Mittal, 2000; Chang and Wang,2011; Yang \& Peterson, 2004, Cronin et al., 2000; Hellier et al.,2003; Hume \& Mort, 2010; Lai et al,2009; Lam et al., 2004; Edward \& Sahadev,2011; Roig et al,2009). In addition, the focus of this study was mainly on software industry. This area has rarely been addressed.

More empirical studies in different companies are suggested for future research. Also it would be insightful to include consequent factors such as customer loyalty and firm profitability since they are the ultimate goals of any company.

\section{References}

Anderson, E.W., \& Mittal, V. (2000). Strengthening the satisfaction-profit chain. Journal of Service Research, 3(2), 107-120. http://dx.doi.org/10.1177/109467050032001

Andreassen, T.W., Lindestad, B. (1998), "Customer loyalty and complex services", International Journal of Service Industry Management, Vol. 9 No.1, pp.7-23. http://dx.doi.org/10.1108/09564239810199923

Babin BJ, Darden WR, Griffin M . Work and/o r fun? Measuring hedonic and utilitarian shopping value. J ConsumRe s 1994;20(4):6 44 -56.

Bitner, M.J., Hubbert, A.R., 1994. Encounter satisfaction versus overall satisfaction versus quality. In: Bolton, R.N., Drew, J.H. (1991), "A multistage model of customers' assessment of service quality and value", Journal of Consumer Research, Vol. 17 pp.375-84.b

Boshoff, C., \& Gray, B. (2004). The relationships between service quality, customer satisfaction and buying intentions in the private hospital industry. South African Journal of Business Management, 35 (4), 27-37.

Burns, M., Woodruff, R. (1992), "Delivering value to consumers: implications for strategy development and implementation", in Allen, C., Madden, T., Shimp, T., Howell, R., Zinkan, G., Heisley, D., Semenik, R., Dickson, P., Zeithaml, V., Jenk, R. (Eds),Marketing Theory and Application, American Marketing Association, Chicago, IL, pp.209-16.

Cameran, M., Moizer, P. and Pettinicchio, A. 2010. Customer satisfaction, corporate image, and service quality in professional services. The Service Industries Journal, 30(3): 421-435. http://dx.doi.org/10.1080/02642060802236111

Chang Hsin Hsin, Wang Hsin-Wei, (2011) "The moderating effect of customer perceived value on online shopping behaviour", Online Information Review, Vol. 35 Iss: 3, pp.333 - 359 
Clottey, T. A., and Collier, D.A. (2008). "Drivers of Customer Loyalty In A Retail Store Environment." Journal of Service Science, 3rd Quarter, Cronin, J., Brady, M., \& Hult, G. (2000). Assessing the effects of quality, value, and customer satisfaction on behavior intentions in service environments. Journal of Retailing, 76(2), 193-218.

Deng, Z., Lu, Y., Wei, K.K. and Zhang, J. (2010) 'Understanding customer satisfaction and loyalty:an empirical study of mobile instant messages in China',International Journal of Information Management,Forthcoming issue, Vol. 30, No. 4, pp.289-300

Edward Manoj, Sahadev Sunil, (2011) "Role of switching costs in the service quality, perceived value, customer satisfaction and customer retention linkage", Asia Pacific Journal of Marketing and Logistics, Vol. 23 Iss: 3, pp.327 345

Eggert, A., \& Ulaga, W. (2002). Customer perceived value: A substitute for satisfaction in business markets. Journal of Business \& Industrial Marketing, 17(2-3), 107- 118. http://dx.doi.org/10.1108/08858620210419754

Erdem, T., Swait, J. (1998), "Brand equity as a signaling phenomenon", Journal of Consumer Psychology, Vol. 7 No.2, pp.131-57. http://dx.doi.org/10.1207/s15327663jcp0702_02

Fiol, L., Alcaniz, E., Tena, M., Garcia, J. (2009), "Customer loyalty in clusters: perceived value and satisfaction as antecedents", Journal of Business-to-Business Marketing, Vol. 16 No.3, pp.276-316 http://dx.doi.org/10.1080/10517120802496878

Fornell C, Johnson MD, Anders on EW, Cha J, Bryant BE. The American customer satisfaction index: nature, purpose, and findings. J Mark 1996;60(4):7 - 18 . http://dx.doi.org/10.2307/1251898

Gronroos, C. (1984), "A service quality model and its market implications", European Journal of Marketing, Vol. 18 No.4, pp.36-44. http://dx.doi.org/10.1108/EUM0000000004784

Heide,J.B.,\& Weiss,A.M.(1995).Vender consideration and switching behavior for buy- ers in high-technology markets. Journal of Marketing, 59, 30-43. http://dx.doi.org/10.2307/1252117

Hellier, P.K., Geursen, G.M., Carr, R.A., Rickard, J.A. (2003), "Customer repurchase intention, a general structural equation model", European Journal of Marketing, Vol. 37 No.11/12, pp.1762-800. http://dx.doi.org/10.1108/03090560310495456

Heskett, J.L., Sasser, W.E., \& Hart, C.W. (1990). Service breakthroughs. New York: The Free Press.

Heskett,J.L.,Jones,T.O.,Loveman,G.W.,Sasser,E.W.,\& Schlesinger,L.(1994).Putting the service-profit chain to work. Harvard Business Review, 72, 164-174.

Hume M; Mort G. S., (2010), "The consequence of appraisal emotion, service quality, perceived value and customer satisfaction on repurchase intent in the performing arts", Journal of Services Marketing, Vol. 24, PP. 170-182.

Kettinger, W.J., Park, S.H., Smith, J. (2009) "Understanding the consequences of information systems service quality on IS service reuse", Information \& Management Online, Vol.46 No.6 pp335-341

Kettinger, W.K., Lee, C.C. (1997) "Pragmatic perspectives on the measurement of information systems service quality", MIS Quarterly, Vol.21 No.June pp223-40 http://dx.doi.org/10.2307/249421

Lai F; Griffin M ; Babin B J, (2009), "How quality, value, image, and satisfaction create loyalty at a Chinese telecom", Journal of Business Research 62,PP. $980-986$

Lam SY, Shankar V, Erramilli MK, Murthy B. Customer value, satisfaction, loyalty, and switching costs: an illustration from a business-to-business service context. Acad Mark Sci J 2004;32(3):293. http://dx.doi.org/10.1177/0092070304263330

Ma, Q., Pearson, J.M., Tadisina, S. (2005), "An exploratory study into factors of service quality for application service providers", Information \& Management, Vol. 42 No.4, pp.1067-80. http://dx.doi.org/10.1016/j.im.2004.11.007

Molinari L. K.; Abratt R.; Dion P., (2008), "Satisfaction, quality and value and effects on repurchase and positive word-of-mouth behavioral intentions in a B2B services context", Journal of Services Marketing, Vol. 22, PP. 363-373.

Morgan, N.A., Anderson, E.W., \& Mittal, V. (2005). Understanding firms' customer satisfaction information usage. Journal of Marketing, 69 (3), 131-151. http://dx.doi.org/10.1509/jmkg.69.3.131.66359

Oliver, R. (1997), Satisfaction: A Behavioral Perspective on the Consumer, McGraw-Hill, NewYork, NY.

Oliver, R. L. (1999). Whence consumer loyalty? Journal of Marketing, 63(4), 33-44. http://dx.doi.org/10.2307/1252099

Parasuraman, A. (1997), "Reflections on gaining competitive advantage through customer value", Journal of the Academy of Marketing Science, Vol. 25 No.2, pp.154-61. http://dx.doi.org/10.1007/BF02894351

Parasuraman, A., Berry, L. and Zeithaml, V. (1991), "Refinement and reassessment of the SERVQUAL scale", Journal of Retailing, Vol. 67 No. 1, pp. 39-48.

Parasuraman, A., Zeithaml, V. and Berry, L. (1994), "Refinement alternative scales for measuring service quality: a comparative assessment based on diagnostic criteria", Journal of Retailing, Vol. 70 No. 3, pp. 201-30. http://dx.doi.org/10.1016/0022-4359(94)90032-9. http://dx.doi.org/10.1016/0022-4359(94)90033-7 
Parasuraman, A., Zeithaml, V.A., \& Berry, L.L. (1985). A conceptual model of service quality and its implications for future research. Journal of Marketing, 49 (4), 41-50. http://dx.doi.org/10.2307/1251430

Parasuraman, A., Zeithaml, V.A., \& Berry, L.L. (1988). SERVQUAL: A multiple-item scale for measuring consumer perceptions of service quality. Journal of Retailing, 64, 12-40.

Paulssen, M. and Birk, M.M. (2007), "Satisfaction and repurchase behavior in a business-t o-business setting: investigating $t$ he moderating effect of manufacturer, comp any and demog ra phic characteristics", Industrial Marketing Management, Vol. 36 No. 7, p p. 983-97.

Boksberger Philipp E., Melsen Lisa, (2011) "Perceived value: a critical examination of definitions, concepts and measures for the service industry", Journal of Services Marketing, Vol. 25 Iss: 3, pp.229 - 240 http://dx.doi.org/10.1108/08876041111129209

Pollack, B.L. (2008) "The nature of the service quality and satisfaction relationship: empirical evidence for the existence of satisfiers and dissatisfiers", Managing Service Quality, Vol.18 No.6 pp537-58 http://dx.doi.org/10.1108/09604520810920059

Richard, M.D. and Allaway, A.W. 1993. Service Quality Attributes and Choice Behavior. Journal of Services Marketing, 7(1): 59-68. http://dx.doi.org/10.1108/08876049310026105

Roig JCF, Garcia JS, Tena MAM (2009). Perceived value and customer loyalty in financial services. Serv. Ind. J. 29:775-789. http://dx.doi.org/10.1080/02642060902749286

Saha G. C; Theingi, (2009), "Service Quality, Satisfaction, and Behavioural Intentions", Managing Service Quality, Vol. 19, PP. 350-372.

Sanchez, J., Callarisa, L.L.J., Rodriguez, R.M., \& Moliner, M.A. (2006). Perceived value of the pur- chase of a tourism product. Tourism Management, 27(3), 394-409. http://dx.doi.org/10.1016/j.tourman.2004.11.007

Shin, D.-H., \& Kim, W.-Y. (2008). Forecasting customer switching intention in mobile service: An exploratory study of predictive factors in mobile number portability.Technological Forecasting \& Social Change, 75(6), 854-874. http://dx.doi.org/10.1016/j.techfore.2007.05.001

Spreng, R.A., MacKenzie, S.B. and Olshavsky, R.W. (1996), "A reexamination of the determinants of consumer satisfaction", Journal of Marketing, Vol. 60, pp. 15-32. http://dx.doi.org/10.2307/1251839

Teas, K., \& Agarwal, S. (2000). The effects of extrinsic product cues on consumers' perceptions of quality, sacrifice and value. Journal of the Academy of Marketing Science, 28(2), 278-290. http://dx.doi.org/10.1177/0092070300282008

Ueltschy, L.C., Laroche, M., Eggert, A., \& Bindl, U. (2007). Service quality and satisfaction: An international comparison of professional services perceptions. Journal of Services Marketing, 21 (6), 410-423. http://dx.doi.org/10.1108/08876040710818903

Wang C. Y.,(2010), " Service Quality, Perceived Value, Corporate Image, and Customer Loyalty in the Context of Varying Levels of Switching Costs", Psychology \& Marketing, Vol. 27, PP. 252-262.

Woodruff, R.B. (1997). Customer value: The next source of competitive advantage. Journal of the Academy of Marketing Science, 25(2), 139-153. http://dx.doi.org/10.1007/BF02894350

Yang, H.-E., Wu, C.-C., \& Wang, K.-C. (2009). An empirical analysis of online game ser- vice satisfaction and loyalty. Expert Systems with Applications, 36(2), 1816-1825. http://dx.doi.org/10.1016/j.eswa.2007.12.005

Yang, Z., \& Peterson, R.T. (2004). Customer perceived value, satisfaction, and loyalty: The role of switching costs. Psycology and Marketing, 21(10), 799-822. http://dx.doi.org/10.1002/mar.20030

Yi, Y., 1990. A critical review of customer satisfaction. American Marketing Association, Chicago.

Zeithaml V. A., Bitner M. J., Gremler D. D. (2006) Services marketing, 4th edition, McGraw-Hill.

Zeithaml, V.A. (1988), "Consumer perceptions of price, quality, and value: a means end model and synthesis of evidence", Journal of Marketing, Vol. 52 No.3, pp.2-22. http://dx.doi.org/10.2307/1251446

Zeithaml, V.A. and Bitner, M.J. (1996), Services Marketing, The McGraw-Hill Companies, New York, NY.

Zeithaml, V.A., Parasuraman, A., Berry, L.L., 1990. Delivering Quality Service: Balancing Customer Perceptions and Expectations. The Free Press, New York, NY. 
Table 1. Results of factor analysis

\begin{tabular}{|c|c|c|c|}
\hline & Item & Standardized loading & Cronbach alpha \\
\hline \multirow[t]{3}{*}{ Service Quality (Reliability) } & REL1 & .767 & 0.829 \\
\hline & REL2 & .735 & \\
\hline & REL3 & .823 & \\
\hline \multirow[t]{4}{*}{ Service Quality (Responsiveness) } & RES1 & .868 & \\
\hline & RES2 & .828 & \\
\hline & RES3 & .883 & \\
\hline & RES4 & .858 & \\
\hline \multirow[t]{3}{*}{ Service Quality (Assurance) } & AS1 & .771 & \\
\hline & AS2 & .788 & \\
\hline & AS3 & .774 & \\
\hline \multirow[t]{4}{*}{ Service Quality (Empathy) } & EMP1 & .774 & \\
\hline & EMP2 & .813 & \\
\hline & EMP3 & .790 & \\
\hline & EMP4 & .781 & \\
\hline \multirow[t]{3}{*}{ Service Quality (Tangible) } & TAN1 & .820 & \\
\hline & TAN2 & .810 & \\
\hline & TAN3 & .829 & \\
\hline \multirow[t]{3}{*}{ Customer Perceived Value } & CPV1 & .904 & .744 \\
\hline & $\mathrm{CPV} 2$ & .935 & \\
\hline & CPV3 & .945 & \\
\hline \multirow[t]{4}{*}{ Satisfaction } & SAT1 & .925 & .844 \\
\hline & SAT2 & .949 & \\
\hline & SAT3 & .886 & \\
\hline & SAT4 & .940 & \\
\hline
\end{tabular}

Table 2.Service quality model fitness indices

\begin{tabular}{|l|l|}
\hline fitness indices & Measure of Index \\
\hline Chi-Square/df & 2.4305 \\
\hline P-value & 0.000 \\
\hline Root Mean Square Error of Approximation (RMSEA) & 0.079 \\
\hline Goodness of Fit Index (GFI) & 0.96 \\
\hline Adjusted Goodness of Fit Index (AGFI) & 0.93 \\
\hline
\end{tabular}

Table 3.The Structural model fitness indices

\begin{tabular}{|l|l|}
\hline Fitness indices & Measure of Index \\
\hline Chi-Square/df & 1.8304 \\
\hline P-value & 0.000 \\
\hline Root Mean Square Error of Approximation (RMSEA) & 0.062 \\
\hline Goodness of Fit Index (GFI) & 0.91 \\
\hline
\end{tabular}




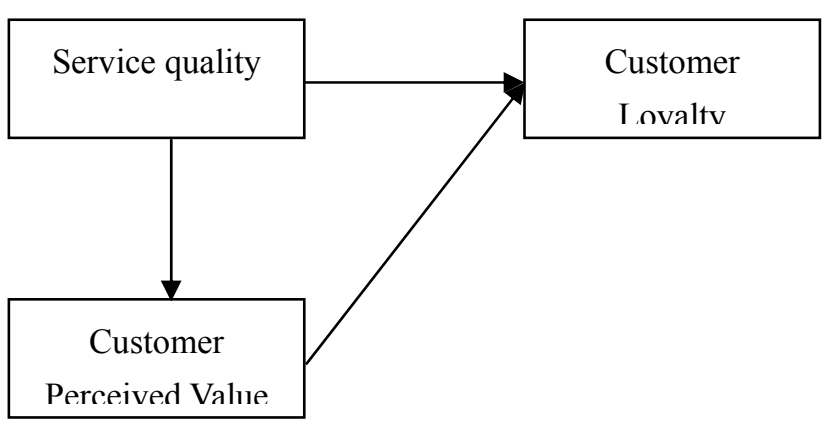

Figure 1. Proposed conceptual model

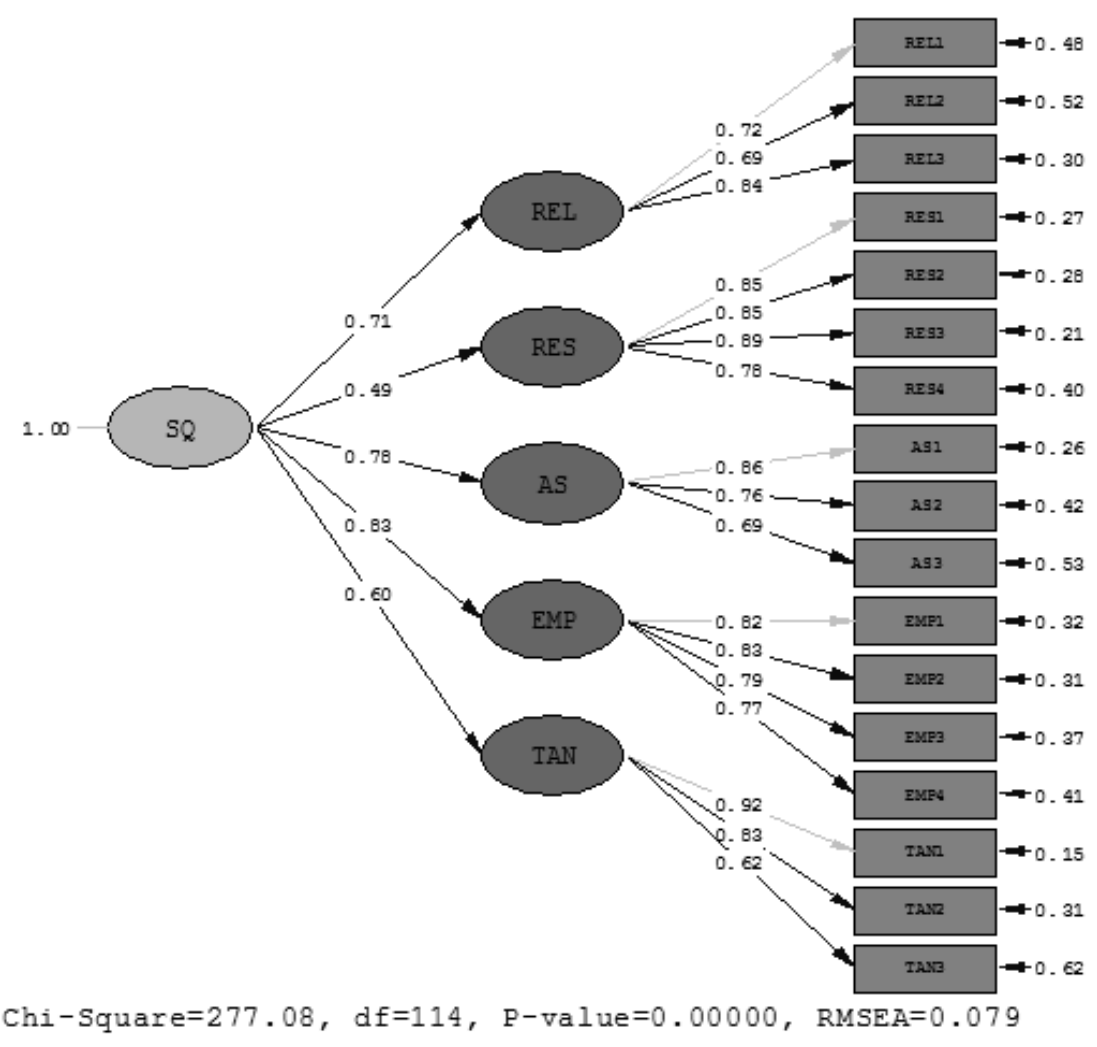

Figure 2.Standardized Solutions Model for SQ 


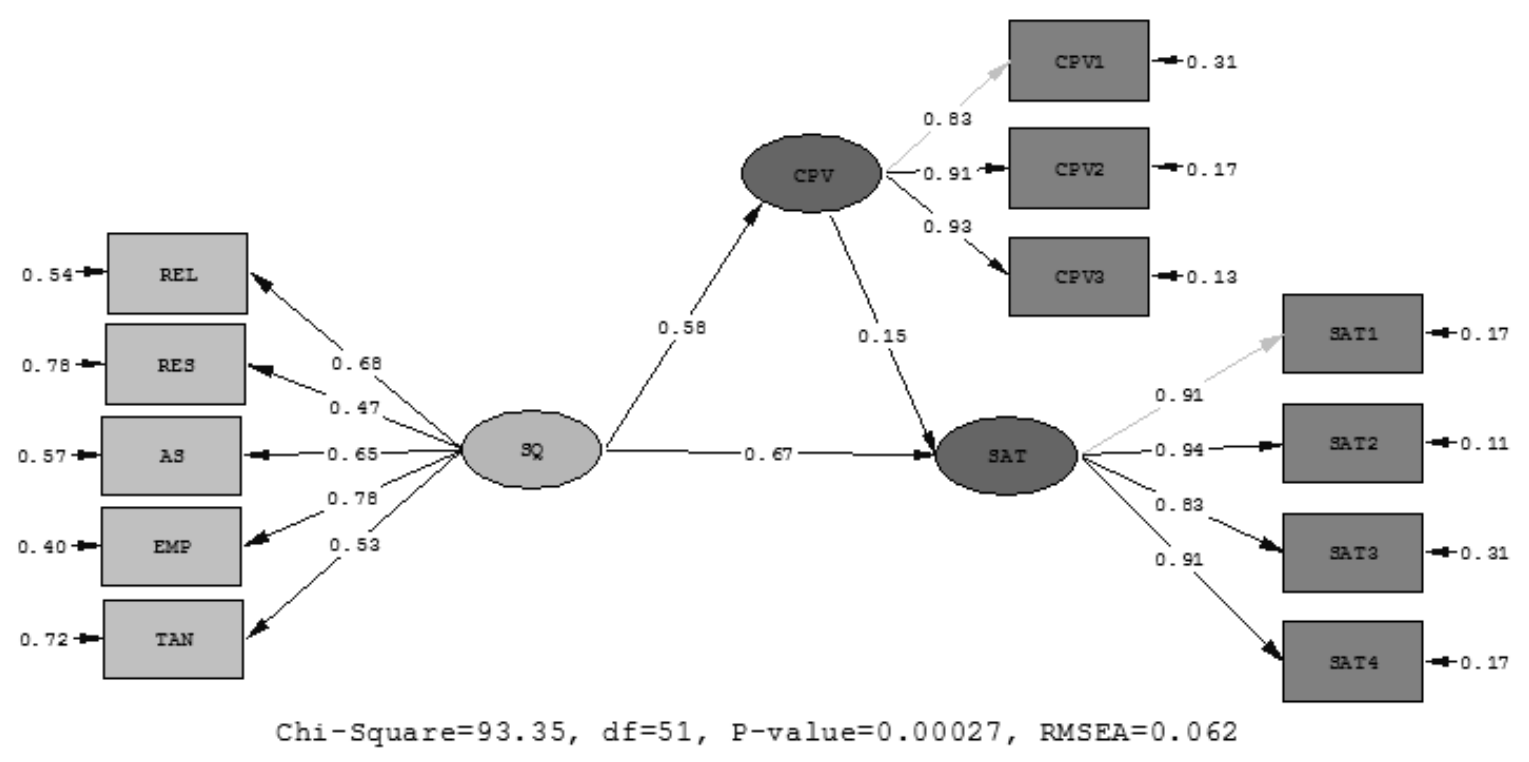

Figure 3. Structural model 